on artisans." The Department desires to call the serious aitention of the Committees of Schools to this instruction where fees are not imposed. They find that in some places not only is there an enire absence of fees, tut that there has even been an unseemly competition on the part of teachers to get students by any means to join their classes with a view of earning the payments on results. They therefore give notice to the Committees of Schools that unless they themselves take steps to remedy the present eviis by imposing at least sonie small fees, which should be paid to the Committee direct, it will be necessary to reduce the amount of the payments on results. They have no wish to reduce the piyments on results at present, and they would avoid as long as possible the imposition of new conditions which necessarily complicate the system of aid, and render the rules burdensome and difficult to work under, but the want of prorer vigilance on the part of the Committees may render this step necessary.

\section{AUGUSTUS DE MORGAN}

$\mathrm{T}^{\mathrm{H}}$ OSE readers of NATURE who are in the habit of examining the obituary column of the Times, will have regretted to see, on Monday morning last, the announcement of the death of the eminent mathematician, Augustus De lilorgan. He had been seriously ill for the past two years. A disease of the kidneys, complicuted with other disorders, had reduced him to a shadow of his former self, and rendered him incapable of any protract:d exertion. This was the more trying as his mind retained all its former energy, and the doctors forbade his rearling more than an hour or two in the day. He was, however, allowed to see his friends, and often amused and irstructed them by the hour together from the stores of his extraordinary memory. During the last few weeks he had become considerably weaker, and on Saturday the $18 \mathrm{th}$, at one o'clock in the afternoon, his spirit was released from the body which for so many months had been orily a burden to it.

Augustus De Morgan was the son of a Colonel in the Madras army. He could trace his descent from the mathematician, James Dodson, author of the "Anti-Logarithmic Canon." He was born in the summer of 1806 , in Southern India. While yet a school-boy, he showed his taste for mathematics by filing thick notebooks with "infinite series," which he interspersed with grotesque figures and quaint faces. In 1823 he went to Cambridge, where he entered at Trinity College; his rooms were in the south-east comer of the great court, then called "Mutton Hole Conner," which he affirmed was a contraction from Merton Hall Corner.

In the tripos of 1827 he was Fourth Wrangler, but he never proceeded to the degree of M.A., owing to his objection to subscribe to the tests, and it is sad to think that the same conscientious scruples debarred this iilustrious man from a Fellowship. On leaving Cambridge he entered at Lincoln's Inn, and would have forsaken Mathematics for the study of the Law, but that in 1828 , the London University, now University College, was founded, and he was offered the Professorship of Mathematics there, which he accepted, and remained a firm supporter of the College and its principle of no tests till the year 1866 , when the Ccuncil, in making an appointment to the chair of Logic arid Mental Phi osophy, refused, as the Professor believed, one of the candidates in account of his religious opinions. Prof. De Morgan remon. sirated, Lut his remonstrarces weie disreyarded. He then thought it his duty to inform them that he must forsake the College if the College forscok its principles. But the Council turned a deaf ear; and Prof. de Morgan who had for nearly forty years been the chief honour and orrament of their institution, left them, and, we are informed, nerce afterwards entered the ir gates.
To Estimate the energy of the Prufessor we must lock at him rot only as a tcach:r of mathematics, but as a mathematician, an actuary, a logician, an historian, a biographer, aud a bibliophile. First, then, as a teacher of mathematics perhaps nomin has been more successful in training distinguished mathematicians. Amongst the latter we may mention the names of Prof. Clifton, Judge Hargreave, Mr. Routh, and Mr. Todhunter. Prof. Sylvester a!so attended his leciures, though the rclationship of professor and pupil did not in this case last very long. He had a method of intcresting his hearers in the subjects on which he lectured, and of making them love mathematics forits own sake, which few othermen haveever attained tc. He expended a great deal of work upon his classes. The subject-matter of tvery lecture which he delivered was entered in a note-book and sent into the library of the college for the beneft of his pupils while writing out and expanding their own notes.

As a mathematician, his work was so various that it is difficult for aby one man to review it, and it would be out of place to attempt anjthing of the kind here; but we may allude in passing to his double algebra, which was $c$ si tainly the for erunner of Quarternions, and contained the geometrical interpretation of the symbol $\sqrt{-1}$. Sir W. R. I ism.iton, in the preface to his Leciures on Quaternions, p. 4I, says, "I3ut I wish to mention that among the circumstances which assisted to prevent me from losing sigit of the general subjects, and from wholly abandonin: the attempt to turn to some useful account those early speculaticn; of mine, on triplets and on sets, was probibly ti.e pullication of Prof. De Morgan's first paper on the 'Foundation of Algebra,' of which lie sent me a copy in 1041. ."

As a writer of mathematical text books, he tcok the highest rink, his books being more suitable, l. owever, for teachers than for pupils. They were characterised by extreme clearness, exhaustiven ss, and sugyestiveness. Perhaps those best known are his "Elements of Atithmetic," published I $83^{\circ}$; his " Elemonts of Alg tbra," pub. lished 1835 ; and his "Differential and Intersial Ca:culuc, with elementary illustrations," which i i a pirf ct mine of original thought, and in which sone of tie most important extensions which the subject has since receive. tinctly indicated, and it was published by the socicty for the Diffision of Useful Knowledge.

As an actuary he occupied the first place, though he was not directly associated with any particular office, but his opinion was sought for on all sides, by actuaries, on questions connected with the theory of yrobabiities as applied to life contingencies. In 1838 he wrote his "Essay on Probabilities," which still retains a high place among the literature of insurance offices.

As a logician he was well known, and his "Formal Logic," together with the Treatise of Mr. Boole, may be said to have created a new era in logical science. His controversy with Sir William Hamilton will long be remembered.

As an historian and biographer, the Engiish Encyclopadia says of him that "he had a great affection for, and an extensive and minute erudition in, all kinds of literary history, biography, and antiquities." He was one of the most extensive contributors to the Penny Cyclopadia. many of the articles of scientific biography having been written by him, as well as most of the mathematical and astronomical articles. The lives of Newton and Halley in Knight's "British Worthies," were also from his pen.

As a bibliophile, his "Arithmetical Books from the Invention of Printing to the Present Time, 1847 ," and his "Budget of Paradoxes" will long remain celebrated. $\mathrm{He}$ was the possessor of a very large collection of old mathematical works.

In addition to this the Professor contributed largely to the Philosophical Magraine, the North British Reviezt, the Athenaum, and the Transactions of the Cambridge Philoscphical Society, in which he publiched most of his 
original investigations. He wrote a "Book of Almanacs," with an Index of Reference, by which the Almanac may be formed for every year up to A.D. 2000, with means of finding the day of the new moon from B.C. 2000 to A.D. 2000. He was also secretary and member of the Council of the Rryal Astronomical Society for many years. He and his son, George De Morgan, also a mathematician of great promise, whose untimely death will be remembered, took the most active part in the foundation of the London Mathematical Society, of which he was the first president. Prof. De Morgan will be buried on Thursday, the $23 \mathrm{rd}$, at Kensal Green, but his memory will long be cherished among a large circle of attached and admiring friends.

ARTHUR C. RANYARD

\section{PAPERS ON IRON AND STEEL}

\section{IV.-The Bessemer Process (continued).}

THE magnificent shower of sparks which accompanies the turning over of the converter is easily explained. The blast has, of course, to be maintained during this turning over, until the whole of the melted material is clear of the openings through which the blast is forced. As these cover a considerable area at the bottom of the converter, the edge of the liquid passes them successively, and at the moment of thus passing the blast cuts the surface of the melted matter almost horizontally. But what is this melted matter? It is a pool of iron, on the top of which is floating a thick scum of silicate of iron, \&c.-the "cinder." I use the term "silicate of iron" only in an approximate sense, as I doubt whether the silica is completely oxidised.

My reasons for doubting it are that the particles which are driven out of the converter by the blast are, to some extent, explosive, they are seen to burst with brilliant coruscations which are partly due to further oxidation; and when the granules which shower upon the floor are examined in the microscope, they present a very curious appearance. They are minute hollow spherules, miniature bomb-shells, varying considerably in diameter from onetenth of an inch to one-fiftieth and less in diameter. The largest are more or less broken, commonly of a basin shape, shown in Figs $I$ and 2.*

The smaller spherules are for the most part perforated. My friend, Mr. Joseph Bragg, who has carefully examined these, and to whom I am indebted for the drawings from which the engravings are copied, says, "I can hardly satisfy myself that any are quite without apertures, though some have no distinct round holes as most have, but in these cases there are minute openings between and under the welded scales or plates which often cover the spherules, giving them a rough surface." Conglomerate groups of these spherules, such as are shown in Figs. $3^{*}$ and 4 , are very common, and some are attached to irregular lumps of cinder, as shown by the right-hand fragment on Fig. 3 . A few are pear-shaped (see Fig. 4). On the right of these pear-shaped specimens are shown some of the smaller spherules in which the perforations are less evident. In the smallest, as the agglomerated and attached specimens (Fig. 3), the perforations are very obscure or doubtful.

Sir Samuel Baker, in his "Nile Tributaries of Abyssinia," describes some natural products due to a similar action on a vastly larger scale, viz., the volcanic eruption of a flood of gaseous matter through fused silicates. He says, "Rows of broken hills, all of volcanic origin, broke the flat plain. Conical tumuli of volcanic slag here and there rose to the height of several hundred feet. We entered a dead level plain of orange-coloured sand, surrounded by pyramidal hills; the surface was strewn with objects resembling cannon shot and grape of all sizes, from a $32-$ pounder downwards; the spot looked like the old battle-

* Figs r, 2, and 3 will be found in last week's number of Natura, p. 320 fields of some infernal region. . . . I dismounted to examine the Satanic bombs and cannon shot. Many of them were as perfectly round as though cast in a mould, others were egg-shaped, and all were hollow. With some difficulty I broke them, and found them to contain a bright red sand; they were, in fact, volcanic bombs that had been formed by the ejection of molten lava to a great height from active volcanoes; these had become globular in falling, and having cooled before they reached the earth, they retained their forms as hard spherical bodies precisely resembling cannon shot. The exterior was brown, and appeared rich in iron. The smaller specimens were the more perfect spheres, as they had cooled quickly, but many of the heavier masses had evidently reached the earth when only half solidified, and had collapsed in falling. The sandy plain was covered with such vestiges of volcanic action, and the infernal bombs lay as imperishable relics of a hailstorm such as may have destroyed Sodom and Gomorrah." To a Lilliputian traveller about an inch and a quarter high the floor of a Bessemer shop would present about the same aspect as this volcanic plain presented to Sir Samuel Baker, and would appear on about the same scale relative to the traveller's own dimensions.
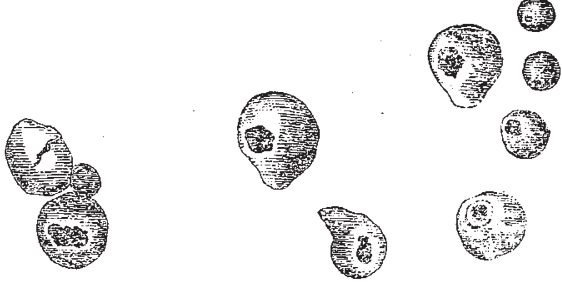

FIG. 4.

It may have been remarked that in the above I have never used the word "slag," which in chemical works is usually applied to the separated silicate of iron, \&c., however it may have been separated. I have called it "cinder," in accordance with the nomenclature of the workshop, for in the use of these terms, slag and cinder, the workshop is more learned than the University, even in the matter of etymologies, which occupies so absorbing an amount of University attention.

Whenever the silicate is separated by fusion or the direct action of the fire he calls it "cinder," when it is squeezed out from a bloom or pile by the blows of the hammer he calls it "slag." Now the Scandinavian name of fire refuse or dross is sinner, the German for the same is sinter. The Scandinavian for a blow is slag, the German schlag. I have observed with much interest the constancy with which the workman adheres to the strictly etymological signification of these words, while learned writers uttes ly confound them. Of course the workmen are unacqua: nted with their origin, nor have I ever seen their distingetive etymologies pointed out by anybody else. They afford an interesting illustration of the technical continuity of modern English with its ancient Scandinavian basis. Our metal workers, like our sailors, still speak the strong tongue of the old Norseman. There are scientific as well as etymological reasons for the distinction between cinder and slag, and therefore I adopt the workmen's phraseology.

W. Mattieu WrLliams

\section{SCIENCE IN GOVERNMENT WORKSHOPS}

THERE seems to be a singular antagonism between science and officialism. The Government has undertaken more than one special manufacture, and not without a certain measure of success, but even the best of Government factories are tainted with some 